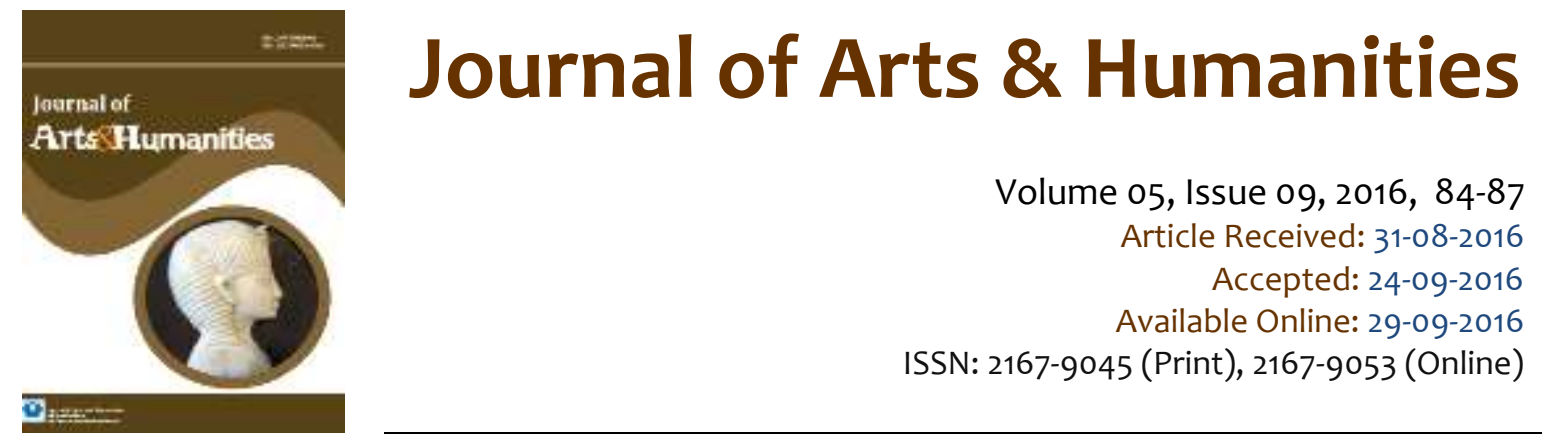

\title{
Some Thoughts on Contemporary Graphic Print ${ }^{1}$
}

\begin{abstract}
Stefan Skiba
ABSTRACT

The production requirements of original graphic works of art have changed since 1980. The development of digital printing using lightfast colors now rivals traditional techniques such as wood cut, screen print, lithography, etching etc. Today, with respect to artistic legitimacy, original graphics using traditional printing techniques compete with original graphics produced by digital printing techniques on the art market. What criteria distinguish traditional printing techniques from those of digital printing in the production and acquisition of original graphics? What consequences is the serious artist faced with when deciding to implement digital print production? How does digital print change original graphic acquisition decisions?
\end{abstract}

Keywords: Art, artist, cultural, culture, technologies, technology.

This is an open access article under Creative Commons Attribution 4.0 License.

\subsection{Introduction}

"It is simply a fact, that artists not only splash paint on canvas and sculpt stones, artists are also researchers." (Fritzsche, 2016).

For five years, I spent every Monday at the Frankfurt Zoo sketching the lions, baboons and a shoe bill stork which, upon seeing me, immediately opened its beak as far as possible and furiously ran towards me with the intention of attacking my box of water colors. Motion studies. The evenings that followed were spent in the largest room of the Kunstschule Westend (Westend Art College) sketching nudes and making portraits. During the week, my time was dedicated to implementing what I had learned from the drawings, making sketches on stone using chalk and India ink, exposing on screens or using sharp knives to make carvings in linoleum. I loved the woody resinous smell that pervaded the workshop, the dark rumbling of the litho press and the shrilly creaking sounds of the rollers of the hand printer. I tried to discover the limits and possibilities offered by the tools I used such as chalks, brushes and palette knives. Somewhere between 1985 and 1986, a fellow student approached me and said: "There are now computers that can do all that a lot better." However, I stubbornly swore to continue using my hands in future and decided to choose "free" graphics instead of "applied" graphics. This paper is not so much concerned with the final phase of my studies in 1990 focusing on massive, uniform, completely

\footnotetext{
1 Translation: Gerald Parker
} 
woodcut and screen print editions, but rather with the fact that every player on the art market can today take advantage of the opportunity of discovering the limits and possibilities provided by state-ofthe-art printing techniques.

\subsection{Methodology}

An observational study was applied for the period 1987 to 2016 taking into account the following:

1. Demarcation criteria between lightfast digital printing and traditional printing techniques (screen printing, woodcut, lithography, etching etc.)

2. The influence of digital printer development on the production and acquisition of artistic original graphics.

\subsection{Analysis and findings}

Today, a wide format ink jet printer represents the most widespread possibility to produce small editions of artistic works. It is, consequently, worthwhile looking into. How can I sum it up? Light, easy to handle and quick. It is characterized by bucking and jerking noises and light-fast colors. Print on command on meter-wide cardboard rolls (30 meter lengths, weight 300g/sq.m). My printer looks like some dark, secretive musical instrument. It saves time (coloring print block, screen exposure etc.), space and storage costs. On the other hand, at first glance it seems to be more complex and more complicated to operate. That means a training course is a prerequisite. I must admit, I like to learn new things and that my curiosity outweighs my need for security - thus my attitude is: Provide me with the know-how. On top of that: Good working conditions, namely sitting and the computer mouse is easy to operate. Also collectors cannot complain. The possibility of print on demand means that I only need to produce a creative work for a pre-defined wall (exhibition, salesroom) when there is a corresponding demand. A prerequisite for this is, however, that original graphics should never be given as gifts. This includes birthday presents, gifts to clubs celebrating anniversaries, wedding presents for relatives etc. This also applies if the cost is more or less zero. "Giving" is not professional, and "more or less" definitely not. Both have the effect of watering down demand and question the artist's professionalism and value on the art market.

Prior to printing a newly developed graphic, I personally stipulate the edition print run. The first printed cardboard sheet is then, just as all subsequent ones, documented in a catalogue of works (Excel spreadsheet or similar). Up to this point, there is no difference between ink jet printing and classical printing techniques. The number one feature of an ink jet edition is the possibility the defined print run is never achieved. Depending on the lifespan of the artist in question and the particular demand of the art enthusiast (no risk - no fun), only five out of thirty sheets, for example, might be printed and signed over a period of seventy seven years. Consequently, the price of each original graphic of a print run of five is much higher than the price per graphic of a print run of thirty. Owing to the exclusiveness of demand-specific formats, the second special feature is the large range of different individual sheet variations. For example, sheet three of thirty was printed with the format $30 \times 40 \mathrm{~cm}$, whilst sheet four of thirty had the dimensions $105 \times 140 \mathrm{~cm}$.

This is also something collectors are particularly keen on. Numbering, signature and possibly manually applied varnish enhance the artwork's rarity and make it unique. Collectors are quite aware that any unsigned, unnumbered image of the same motive is merely a reproduction, in other words a financially worthless copy. In 1993, three years after completing my studies, I changed my attitude towards computer aided creative design and its implementation by means of an inkjet printer from that of being stubbornly negative to being curious. I was curious to discover the limits and opportunities provided by this new technology. Compared to today, the print quality was miserable, the printers exorbitantly expensive and gallery owners joked that exhibitions would have to be conducted in darkened surroundings due to the light-sensitive colors. Today, however, things are different. Modern inkjet printers save the artist an enormous amount of valuable production time. Furthermore, a small and 
comfortable studio is all that is required, and the artist can concentrate all efforts on essential theoretical design aspects.

\subsection{Conclusion}

The change-over to lightfast digital printing means that visual artists have to initially invest more time and effort obtaining technical know-how. Furthermore, it may also be necessary to invest in equipment. However, the use of the new technique has many benefits such as for example:

1. Design: There are an unlimited number of options regarding subject format and color. and

2. Commercial viability: The production of a limited contemporary digital print edition is subject to neither quantitative nor qualitative restrictions owing to wear and tear of the printing block, printing plate or screen. Moreover, the edition is produced on demand, either partially or as individual sheets, over longer periods of time.

Collectors demand that the increasing volume of digital print art is subject to a re-assessment: One that is more consistent (verification of signature, numbering, catalog of works) and enriched with new criteria (varnish). In the case of lightfast digital printing production, greater individual sheet rarity results in all players on the art market requiring a higher level of artistic legitimacy compared to traditional printing techniques.

\subsection{Recommendation}

"The great upheavals arise from the eruption of newcomers who, by the sole effect of their number ... , import innovation regarding products or techniques of production, and try or claim to impose on the field of production, which is itself its own market, a new mode of evaluation of products." (Bourdieu, 2016).

The advantages of original graphics printing using lightfast pigment based inks compared to traditional printing techniques, have led to their increasing popularity and growing acceptance on the art market, and a commercial upgrading. It is, consequently, advisable for the younger generation of artists and collectors to overcome not only barriers, but also their reservations and be open-minded to the digital revolution. This requires a combination of both courage and curiosity.

\section{Further information}

Skiba, Stefan. (2016): Expressive Schwarz-Weiß-Vektorgrafik in der zeitgenössischen Kunst. / Kapitel: Der Wert (Zweck-) Freier Bildender Kunst / Absatz: III. Im Besonderen: Der materielle Wert lichtechter Vektorgrafik, ISBN 978-3000529948, http://shop.skiba.de

Paper on the research report (will be translated into English in 2017)

Skiba, Stefan. (2017): Expressive black-white vector graphics in contemporary art. / chapter: The values (purpose) of visual art / Section: III. In particular: The material value of lightfast color vector graphics

\section{References}

Bourdieu, P. (2001): Die Regeln der Kunst, ISBN 978-3-518-29139-9

Bourdieu, P. (2016): The rules of art, ISBN 9780745617787 (pbk), page 225, third paragraph

Böhringer, J., Bühler, P., Schleich, P. (2014): Kompendium der Mediengestaltung: Produktion und Technik für Digital- und Printmedien (X.media.press) ISBN 978-3642205811

Fritzsche, B. atelier, Die Zeitschrift für Künstlerinnen und Künstler, Nr. 206 4/2016 http://www.atelierverlag.de

Luhmann, N. (1997): Die Kunst der Gesellschaft, ISBN 3-518-28903-9 
Luhmann, N. (2000): Art as a Social System (Meridian: Crossing Aesthetics), ISBN 978-0804739078

Senefelder, A. (2012): Lehrbuch der Lithographie und des Steindruckes, ISBN 978-3864446764 9

Skiba, S. (2015): The monitor acts as my canvas - the use of vector graphics in contemporary art, http://archiv.ub.uni-heidelberg.de/artdok/volltexte/2015/3607

Skiba, S. (2016): Expressive Schwarz-Weiß-Vektorgrafik in der zeitgenössischen Kunst, ISBN 9783000529948

Wojda, F. (2015): Das Sammeln zeitgenössischer Kunst, 2015, ISBN 978-3903004665

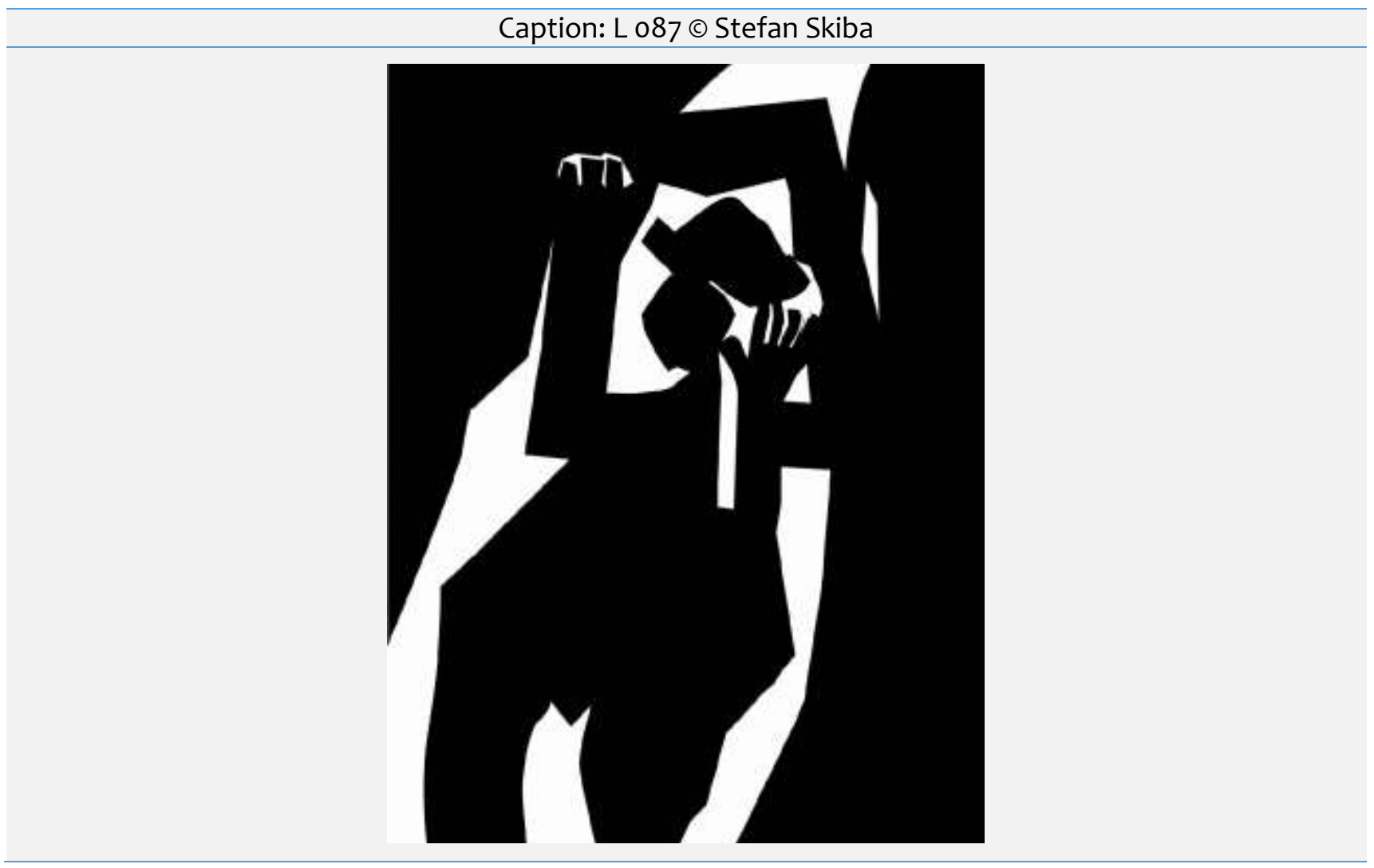

